\title{
Artistic Features Of The Sonnet-Epic
}

\author{
Hamid Mirzaev
}

Teacher, Navoi State Pedagogical Institute, Uzbekistan

\section{ABSTRACT}

The article discusses the experience of creating sonnets and epics in Uzbek poetry, the peculiarities of this genre, the artistic features of sonnets and epics. The author B.Boykobilov's contribution to the creation of works in the genre of sonnet-epic, tried to scientifically describe the experiences and traditions gained in this genre.

KEYWORDS: - Sonnet, genre epic, katren, tertset, misra, band, introduction, conclusion.

\section{INTRODUCTION}

The term "sonnet-epic" entered our literature through the work of Barot Boykobilov. In general, the tradition of composing epics using lyrical genres is present in our literature. But for the first time as a genre the sonnet is included in the composition of such epics. Barot Boykobilov's epic "Child of the Sun" consists of sonnets. The poet reworked this work and published it in "Uzbeknoma" under the title "Uzbekistan I discovered". It contains a hundred sonnets.

The compositional structure of the sonnet-epic "Uzbekistan I discovered" is similar to the composition of classical epics. His preface contains seven sonnets. In it, the poet describes the purpose of the sonnet-epic. The sonnets in the preface are written in both classical and free forms. In general, the epic contains four chapters in addition to the preface; the introductory part is called "murod", and at the end of the epic is given two octaves in the form of "masnavi".

\section{THE MAIN FINDINGS AND RESULTS}

In the sonnet-epic, the poet created a mustazad form of the sonnet. Sonnets 19, 24, and 25 of the epic were written in the form of mustazad, so they became more musical. It is known that in the mustazad, one verse in the ghazal is divided in terms of tone and content, and in the second verse it replaces the divided part of the first verse. The divided parts at the end of the first and second verses rhyme with each other, resulting in a wonderful musicality. That is why Alisher Navoi in his work "Mezon ul-avzon" describes the genre of mustazad as surud (song). B. Boykobilov In the above-mentioned sonnets, the second line in the sonnet quatrain is like the cut, melodically divided part of the first verse. "If I tell you what to do, express my love to you" the first line; "My soul plays between my body" the second line; the first stanza consists of eleven syllables, the second stanza consists of seven syllables. The third and fourth verses have the 
CURRENT RESEARCH JOURNAL OF PHILOLOGICAL SCIENCES 2(6): 51-54,

May 2021 DOI: https://doi.org/10.37547/philological-crjps-02-06-11

ISSN 2767-3758

(C)2021 Master Journals

\section{Crossref do) 8 Google}

Accepted23thJune, 2021 \& Published 28thJune, 2021

same feature. Structurally, a structural resemblance to the genre must be seen. However, this should not lead to the unscientific idea that B. Boykobilov founded a new genre called sonnet-mustazod.

B. Boykobilov not only tested his talent in the genre of sonnets and boldly experimented, but also created a wreath of sonnets, sonnet-epics. Academician B.Valikhodjaev, one of the great scholars of our classical literature, gave one of the fair assessments to his work:

"The poet spent a lifetime in the process of finishing the poem "Dear as bread". But he was not afraid to experiment with various creative tests in this regard. It is safe to say that the poet's research in the genre of ancient sonnets is one of such experiments. True, this genre has its own complexities, whims and melodies. Barot Boykobilov understood that any fourteen lines could not be a sonnet" [1, p. 7].

The sonnet-epic "Samarkand ushshoghi" consists of thirty sonnets. The first sonnet is called "Introduction", the thirtieth sonnet is called "Conclusion". The theme of the epic is a love song. The classic song "Samarkand ushshoghi" is sung in Persian with the ghazal Zebunniso. The song expresses the love, the sufferings of the lover, and the groans of the heart that longs for a friend. Is the epic a taboo, a tasmin, or an interpretation of the ideological and artistic content of this classic song? But in the content of the whole epic there are no lyrical descriptions related to the classical song. The plot of the work is that in Samarkand lives a young writer. His heart is full of goodness and his poems are so dildo that they can conquer any heart. He glorifies love; his heart is full the love. In another tower of the city resides his beloved spring. His musicians and musicians are so charming that the young poet listens to his songs with all his heart, the melodies glorified by fidelity, devotion, and passion captivate him completely, and he longs to live in this melody for the rest of his life. Eventually the walls of separation fall, the poet's dreams come true and he is lucky enough to reach his beloved. It congratulates all on love, wishes well, the poet in love and wishes that the love of the beautiful spring will not perish forever. It is the power of love that inspires the poet to write beautiful poems. The saga ends with a celebration of love, the reunion of two young people, parents and elders congratulating them, wishing them a safe journey, and a wedding hymn.

The sonnet-epic is dedicated to the poet's wife. In the beginning, the verses "From time immemorial, poets sang the emigration, the opportunity left to us" are quoted as epigraphs. In the "Introduction" an attempt is made to state the main artistic and aesthetic purpose of the sonnet-epic. It says that there is a house in the Registan of Samarkand and a penman lives in it. She has a lover and is incredibly beautiful, charming. Nothing can be included in their love, they are so happy, so blissful, they do not know what separation is, so in the poet's poems, not separation, but visol (meeting of lovers) is sung, pure love is honored. It is obvious that the poet's artistic and aesthetic goal is to glorify the love of two young people, to completely forget about separation and to describe the happy moments of the vision. The poet emphasizes this at the end of the "Introduction" that "a heart without separation should play a beautiful melody" [2, p. 56]. The whole ideological content of the epic is dominated by the glorification of this spirit, the glorification of true happiness in love.

Contextual analysis reveals that there are disturbances in the performance of the spiritual functions of the word, semantic inconsistencies. At first glance, the analogy of a "heart without separation" seems to be correct, but the feeling that the heart is not without separation has led to its dimming, and the utterance of a contrasting visol (meeting of lovers) has caused semantic 
CURRENT RESEARCH JOURNAL OF PHILOLOGICAL SCIENCES 2(6): 51-54,

May 2021 DOI: https://doi.org/10.37547/philological-crjps-02-06-11

ISSN 2767-3758

(C)2021 Master Journals

\section{Crossref do) 8 Google}

Accepted23thJune, 2021 \& Published 28 ${ }^{\text {th }}$ June, 2021

inconsistency. Because the melody is not sung, but played.

There are classical and free versions of the sonnet. In the classical round, the last two stanzas consist of three stanzas, and the stanzas of the first and second stanzas are rhymed $a-b-$ $\mathrm{b}-\mathrm{a}$. In a free-form sonnet, the rhyme is $\mathrm{a}-\mathrm{b}-\mathrm{a}$ - b, and verses 13 and 14 are rhymed. In B. Boykobilov's sonnet-epos sonnets belong to free type sonnets. In some sonnets it is also found that the last two verses consist of three verses. But the strict order in rhyming was preserved. Since the sonnet is a small genre of only 14 verses, the meaning attached to each word in it is sublime. To be able to embody a complete life scene in a small lyrical image requires high skill and vast experience from the poet. That's why not everyone dares to tap into the sonnet genre. This can be seen in the example of our national literature. This fact is confirmed by the fact that there are very few artists in Uzbek poetry who have tried their hand at the sonnet genre. Creating an epic based on sonnets is even more difficult, responsible. The epic "Samarkand ushshoghi" is also significant in that it is an experience in creating epics based on sonnets.

In lyricism, the emotional nature of the means of artistic imagery is predominant. The source of emotional perception requires a good knowledge of the possibilities of language, a deep understanding of the criteria of art, the ability to use the subtleties of sound, the subtleties of the meaning of the word. In the sonnet, the importance of this, in particular, increases. Elements of poetic technique such as weight, rhyme, turak, in addition to providing the rhythm of the poem, serve to increase the attractiveness of the sonnet. Drawing portraits of heroes requires an extreme degree of conciseness in the compact poetic genre in depicting natural landscapes. In the first sonnet of the sonnet-epic, some characteristic features of the genre are noted. The first quatrain mentions natural landscapes such as the arrival of spring in the gardens, the opening of tulips in the mountains, the chirping of birds, the roaring of birds, the rushing of water in rivers, the crashing of waterfalls on rocks. All this evokes the beauty of nature, and neither the artist nor the people of the pen are able to give it a proper description. It's as if it's the first time I've encountered such beauty. This spring, the protagonist of the saga wanders along the Siyob River. His heart, too, listens to the tales told by the waves of the river, because of the "sleep of the thoughts" of the river. In harmony with his thoughts, a melody is sung under his ears, emphasizing that he is as pure and priceless as water. The position of the protagonist in the bosom of nature is given through such images, and on this basis his inner feelings, love and joy are emphasized [2].

\section{Conclusion}

The sonnet-epic as a whole consists of love, fidelity, devotion, visual pleasure, singing the trumpet in high tones, calling the people of the world to goodness, love, devotion, which are universal values. This love, the applause in praise of love, the praise is so high that the flight of optimistic feelings knows no bounds. In the twenty-third sonnet, the poet's own aesthetic views on love, fidelity, devotion rise to a high point. It is natural for a smile to appear on the face of a lover who has reached visol (meeting of lovers), who has tasted his pleasure. It is as if the moon rising from the sky is the moon of vision. This is a sign that the moments of separation are completely behind us. When separation is lost, when it is forgotten, then loves, for those who are in love, who are suffering in its pain, affirm that faithfulness to love brings true happiness. In this respect, the protagonist of the saga is extremely happy. For from time immemorial, poets have sung about the heartache of separation when it comes to love. Apart from the 
CURRENT RESEARCH JOURNAL OF PHILOLOGICAL SCIENCES 2(6): 51-54,

May 2021 DOI: https://doi.org/10.37547/philological-crjps-02-06-11

ISSN 2767-3758

(C)2021 Master Journals

Crossief do) 88 Google

Accepted23thJune, 2021 \& Published 28thJune, 2021

hero of the epic, he has achieved his love, he has been happy, so he has no fear of separation, the pain of exile, he does not know infidelity, betrayal of loyalty. He was only happy with the vision, proud of his love. From this point of view, this is the ideal interpretation of love. The ideal of the author of this epic should be seen as an artistic expression of his ideal of glorifying true love, true love, devotion and fidelity, based on his own aesthetic principles.

\section{REFERENCES}

1. Boyqobilov B. (2005) House of Life or Half a Century Office, Selection, Zarafshan Publishing House. - Samarkand. - p. 7.

2. Boykobilov Barot. (2005) Samarkand ushshogi, sonnet-epic, "Hayot mahzani yaki nimr asr devoni". - Samarkand. "Zarafshon" publishing house. - p. 56.

3. Quronov Dilmurod. (2018) Fundamentals of Literary Theory, Textbook. - Tashkent. Navoi University. - p. 7.

4. Tokhliev Boqijon. (2002) Literature (textbook for academic lyceums and professional colleges). - Tashkent: "Teacher". - p. 12.

5. Shodmonov Nafas. (2020) History of Uzbek classical literature, Part one (from the earliest times to the beginning of the XIV century). Textbook, TAFAKKUR Publishing House. - Tashkent: - p. 12. 